\title{
Evolucionismo e interdisciplinaridade na sociologia brasileira: onde está o desenvolvimento regional?
}

\author{
Walter Marcos Knaesel Birkner \\ Centro Universitário Leonardo da Vinci (Uniasselvi) \\ Sandro Luiz Baz:anella \\ Universidade do Contestado (UnC) e Centro Universitário Leonardo da Vinci (Uniasselvi)
}

Recebido: 02/11/2019 Versão revisada (entregue): 13/11/2019 Aprovado: 18/11/2019

\begin{abstract}
Resumo
Este artigo apresenta uma apreciação crítica da Sociologia introdutória no Brasil, indicando a ausência dos conceitos de evolucionismo, desenvolvimento e seu adjetivo "regional", além das dificuldades de abordagem interdisciplinar. Essa dupla constatação se explica pela principal característica da Sociologia que conhecemos e apreendemos a partir do contato com os livros de introdução desta disciplina. Trata-se de reconhecê-la como uma ciência da má distribuição da riqueza e da consequente desigualdade social. Nessa perspectiva, firma-se como uma ciência de crítica à ordem social estabelecida. Por assumir hegemonicamente essa característica, negligencia o reconhecimento de fatores sociais geradores de riqueza, sociologicamente interpretáveis como causas de produção e desenvolvimento regional. E, justamente, devido a essa característica, os conceitos de evolucionismo e desenvolvimento se tornam inconvenientemente dispensáveis. As conclusões são respaldadas por uma investigação bibliográfica feita a partir da leitura dos seis livros de introdução à Sociologia recomendados pelo Ministério da Educação para o triênio de 2015 a 2017.
\end{abstract}

Palavras-chave | Brasil; darwinismo social; desenvolvimento regional; evolucionismo; interdisciplinaridade; sociologia do desenvolvimento.

Código JEL | A14 R58 Z13

\section{Evolutionism and interdisciplinarity in Brazilian sociology: where is regional development?}

\begin{abstract}
This work presents a critical appreciation on the Introductory Sociology in Brazil, indicating the absence of the concepts on evolutionism, development and its adjective "regional", besides the difficulties of an interdisciplinary approach. This double realization is explained by the main characteristic of Sociology that we know and apprehend from the contact with the introduction
\end{abstract}


books of this discipline. It is about recognizing it as a science of the bad distribution of wealth and consequent social inequality. From this perspective, it establishes itself as a critical science to the conventional social order. By assuming this characteristic hegemonically, it despises the recognition of social factors that generate wealth, sociologically interpretable as causes of production and regional development. In addition, precisely because of this characteristic, the concepts of evolutionism and development become inconveniently dispensable. The conclusions are supported by a bibliographic investigation based on the reading of the six introduction books to Sociology, recommended by the Brazilian Ministry of Education for the 2015-2017 triennium.

Keywords | Brazil; evolutionism; interdisciplinarity; regional development; social darwinism; sociology of development.

JEL-Code | A14 R58 Z13

\section{Evolucionismo e interdisciplinariedad en la sociología brasileña: ¿dónde está el desarrollo regional?}

\section{Resumen}

Este artículo presenta una apreciación crítica de la sociología introductoria en Brasil, indicando la ausencia de los conceptos de evolucionismo, desarrollo y su adjetivo "regional", así como las dificultades de un enfoque interdisciplinario. Este doble hallazgo se explica por la característica principal de la sociología que conocemos y aprendemos por contacto con los libros introductorios de esta disciplina. Se trata de reconocerlo como una ciencia de la mala distribución de la riqueza y la consiguiente desigualdad social. Desde esta perspectiva, se erige como una ciencia de crítica del orden social establecido. Al asumir esta característica hegemónicamente, descuida el reconocimiento de factores sociales que generan riqueza, sociológicamente interpretables como causas de producción y desarrollo regional. Y precisamente por esta característica, los conceptos de evolucionismo y desarrollo se vuelven inconvenientemente prescindibles. Las conclusiones están respaldadas por una investigación bibliográfica basada en la lectura de los seis libros de introducción a la sociología, recomendados por el Ministerio de Educación para el trienio 2015 a 2017.

Palabras clave | Brasil; darwinismo social; desarrollo regional; evolucionismo; interdisciplinariedad; sociología del desarrollo.

Codigo JEL | A14 R58 Z13

\section{Introdução}

No prelúdio de "O Gene Egoísta”, de 1976, Richard Dawkins faz uma interessante afirmação a respeito das Ciências Humanas. O autor observa que as disciplinas das "humanidades" praticamente ignoram Charles Darwin, embora acreditasse que o tempo se encarregaria de preencher a lacuna (DAWKINS, 1979, p. 6). E lá se foram 
quatro décadas. Logo na sequência, numa perspectiva declaradamente darwiniana, afirma que ideias ou ideais como o amor e o bem-estar dos seres humanos não passariam de "conceitos que simplesmente não têm sentido na evolução". Naturalmente, tal observação diz respeito à posição de Dawkins sobre o egoísmo como fator genético a partir do qual devêssemos estudar os comportamentos humanos. Embora não tenha chamado a atenção de autores da Sociologia, isso deve nos ajudar a compreender por que o evolucionismo e o desenvolvimento não mereçam desprezo ou menção depreciativa nas abordagens introdutórias da Ciência da Sociedade.

A fim de desenvolver nossa provocação analítica, lembremos o leitor de que a Sociologia é predominantemente uma ciência da desigualdade social e da distribuição imperfeita dos recursos e riquezas socialmente produzidas. Dessa estruturação analítica faz parte uma importante teorização sobre o conceito de desenvolvimento. Pode-se afirmar que ela é erguida a partir da noção de progresso e revestida pela teoria da evolução. Decorrem daí importantes desdobramentos analíticos de crítica ao darwinismo social, até chegar a uma rica e contemporânea produção interpretativa, em curso, sobre o tema do desenvolvimento regional. No entanto, por associadas razões éticas e preferências de método interpretativo que orientam a crítica ao darwinismo social, toda a teorização revisionista ao conceito de desenvolvimento foi revogada da Sociologia introdutória brasileira. E, por extensão, é absolutamente ausente a criativa produção sobre o tema do desenvolvimento regional, enriquecida, por exemplo, pela ideia-força do capital social e temas convergentes.

Não obstante à elucidação analítica que a Sociologia proporcionou acerca do funcionamento das estruturas sociais, essa característica geral de crítica ao "sistema" opera não apenas como uma finalidade. Funciona como um pressuposto metodológico que ao mesmo tempo orienta, mas também limita o alcance interpretativo desta presunçosa ciência. Uma vez que a Sociologia esteja comprometida com a denúncia aos desequilíbrios sociais, isso gera conhecimento especializado e útil à ciência e à política. Contudo, desvia o olhar de certos aspectos que constituem a complexidade das relações sociais e dos efeitos que essas relações são capazes de produzir. E, a despeito dos pronunciamentos em favor da interdisciplinaridade, a Sociologia especializou-se tanto quanto outras ciências filhas da modernidade. Majoritariamente, concentra-se em denunciar a desigualdade e a má distribuição da riqueza, ignorando as origens dela e do desenvolvimento, definindo-se cada vez mais como uma ciência altruísta e mal-humorada.

Por isso, existem dois elementos inerentes ao darwinismo que incomodam uma parcela importante das abordagens sociológicas. Entre elas estão as que encontramos nos manuais de introdução à Sociologia recomendados trienalmente 
pelo Ministério da Educação do Brasil (MEC) ${ }^{1}$. O primeiro desses elementos é o pressuposto de uma perspectiva comportamental egoísta. Mais do que o individualismo metodológico que reconhecemos na perspectiva analítica de Max Weber, o pressuposto do egoísmo sugere que a conformação da sociedade estaria, antes de tudo, baseada na busca do interesse próprio. É o que aparece, por exemplo, na teoria da escolha racional na Ciência Política, inexistente nos manuais de Sociologia. Ora, se tomado como pressuposto metodológico, o egoísmo dificultaria, quando não inviabilizaria as abordagens filantrópicas que nos parecem familiares. De fundo moral altruísta, insinuam o amor ao próximo, o combate às desigualdades e às injustiças, bem como a defesa do bem-estar social. Afinal, não basta interpretar o mundo, sendo preciso transformá-loº

O segundo pressuposto inerente às observações de Darwin e estendido à análise da Sociedade pelo darwinismo social é o da competição. Evidentemente, esse pressuposto é um prolongamento do egoísmo natural. Se a "natureza humana" é, no princípio de tudo, egoísta, então será óbvio que os homens competirão entre si. Antes mesmo de Charles Darwin, clássicos da teoria política moderna já o intuíam. Machiavel e Hobbes, a quem a Sociologia deve parte importante de sua gênese, partiram desse pressuposto sem receios. E, ainda que não passe de uma suposição lógico-dedutiva, é possível que o pressuposto do egoísmo nas formulações desses e de autores precedentes tenha influenciado Darwin. É possível, também, que o ambiente "selvagem" do capitalismo da Revolução Industrial o tenha influenciado. Especulações. De concreto, sabemos que o criador do evolucionismo inspirou os pensadores sociais do seu tempo e posteriores. Originou o darwinismo social, tão criticado, rechaçado e hoje praticamente ignorado nos manuais de Sociologia.

Ao contrário de ignorar, bem fariam os autores dos livros de introdução à Sociologia em reafirmar a crítica ao darwinismo social. Seria o ponto de partida para uma recuperação do conceito de desenvolvimento em novo patamar. Ao fazê-lo, muito contribuiriam com jovens leitores de uma disciplina desatualizada sobre este ponto. Como conceito e fenômeno, o desenvolvimento continua no centro das reflexões das ciências humanas em geral e armazena contribuições cada vez mais interdisciplinares. Nessa direção, as investigações e publicações sobre o tema do desenvolvimento regional têm trazido novos ares. As preocupações e descobertas sobre os conceitos de região, local e território trouxeram à cena um universo temático e conceitual instigante. Aproximações aparentemente incompatíveis entre, de um lado, cooperação e associativismo e, de outro, competição e inovação, têm gerado renovadas interpretações teóricas e expectativas políticas. Além disso,

\footnotetext{
1 A cada triênio, o Ministério da Educação do Brasil (MEC) recomenda os livros a serem utilizados no ensino público do país por meio do Programa Nacional do Livro e do Material Didático (PNLD).

${ }^{2}$ Esta é a $11^{\mathrm{a}}$ das Teses sobre Feuerbach, publicadas pela primeira vez por Engels, em 1888, como apêndice à edição em livro de "Ludwig Feuerbach e o fim da Filosofia Alemã Clássica", Stuttgart, 1888, p. 69-72. Publicado segundo a versão de Engels de 1888, em cotejo com a redação original de Marx.
} 
engendrarão, cedo ou tarde, uma recuperação do evolucionismo de Darwin, como reclama Dawkins, substituindo uma interpretação equivocada, produzida pelos darwinistas sociais.

\section{Anti-evolucionismo}

Quantas obras foram analisadas? Qual foi o método de amostragem e análise? E como o material é significativo para caracterizar a "sociologia introdutória no Brasil"?

O darwinismo social do Século XIX foi o alvo de uma dura e, até certo ponto, correta crítica sociológica, como veremos à frente. Isso feito, foi abandonado sem maiores explicações. Em uma investigação que fizemos sobre os conteúdos de livros didáticos brasileiros de Sociologia, esse abandono do evolucionismo é perceptível. Trata-se de escrito ainda não publicado, provisoriamente intitulado "Distribuição e desigualdade versus produção e desenvolvimento: uma antítese oculta nos manuais de Sociologia". É resultado de uma leitura atenta dos seis livros didáticos de Sociologia para o ensino médio, recomendados pelo Programa Nacional do Livro Didático (PNLD), para o triênio 2015-2017. A investigação revelou dois aspectos importantes aos nossos fins: 1) a inexistência de uma revisão sobre o evolucionismo e o conceito de desenvolvimento nas ciências sociais e 2) a quase inobservância a fenômenos sociais reunidos na ideia-força de capital social e suas relações com o desenvolvimento regional. Neste segundo aspecto, deve-se mencionar a exceção em Machado, Amorim e Barros (2013), que dedicam as páginas 297 a 300 sobre o capital social.

Para a disciplina de Sociologia, o Ministério da Educação (MEC) recomendou seis livros, que são os seguintes: 1) Araujo, Bridi e Motim, 2013; 2) Bomeni et al., 2013; 3) Machado, Amorim e Barros, 2013; 4) Oliveira e Costa, 2013; 5) Silva et al., 2013; e, finalmente, 6) Tomazi, 2013). Essa recomendação é, na sua última etapa avaliativa, o resultado do trabalho de avaliadores ad hoc de várias universidades brasileiras. Vale dizer que se trata de uma avaliação minuciosa que responde a 110 perguntas organizadas a partir de um conjunto de critérios. Ali, consideram-se aspectos teóricos e conceituais, didático-pedagógicos, de legislação, imagens, editoração, entre outros. A avaliação contém, ainda, as resenhas críticas de cada um dos livros e está publicada no Guia dos Livros Didáticos de Sociologia do PNLD (BRASIL, 2014). Não menos importante é a consideração de um amplo conjunto de componentes das três unidades curriculares da disciplina, que correspondem a cada um dos três anos do ensino médio. Essas unidades e seus componentes orientam os conteúdos dos manuais e estão publicados na Base Nacional Curricular Comum (BNCC) (BRASIL, 2016, p. 648-51). 
Quanto à leitura dos livros, fizemos a comparação entre os mesmos e, em geral, como se poderia esperar, existe convergência na abordagem entre eles. Nosso propósito hipotético foi averiguar a incidência da preocupação desses manuais com o que consideramos a principal característica da Sociologia: sua preocupação com a distribuição da riqueza material e imaterial socialmente produzida e a desigualdade social correspondente. E, por extensão e contraposição, procuramos identificar a presença e o tratamento conferidos a termos, conceitos ou ideias-força que sugerissem a preocupação com a produção dessa riqueza. Nessa perspectiva, estivemos em busca de lacunas sociológicas que viessem a revelar o que podemos chamar de um desinteresse e consequente marginalização sobre o desenvolvimento e seus temas congêneres. Isso não quer dizer que a tematização esteja ausente, já que o desenvolvimento é, por sinal, bastante mencionado. Todavia, o tratamento a ele conferido reforça as preocupações da Sociologia com a distribuição da riqueza e com a desigualdade social, quando esta ciência poderia também se debruçar sobre fatores de produção da riqueza.

Nosso procedimento de investigação consistiu, literalmente, em uma busca de palavras, cuja frequência e regularidade, sugerimos, permita uma caracterização da literatura didática de Sociologia no Brasil. Essa caracterização geral apresenta a Sociologia como uma ciência da má distribuição e da desigualdade social. As apresentações mais convencionais e até mesmo bem definidas dos manuais não sugerem isso de modo literal. Em geral, o papel dessa ciência humana está relacionado ao estudo sobre como as sociedades se formam, o que as mantêm enquanto tais e o que muda ao longo do tempo. Por extensão, aprende-se que a Sociologia estuda as relações entre indivíduo e sociedade e suas influências recíprocas. Mas ao final das leituras de bem elaborados manuais, a impressão que se pode ter é que essa disciplina tem duas facetas, de importantes consequências interpretativas, quais sejam: 1) há realmente uma predominância absoluta da denúncia à má distribuição e à desigualdade social e 2) inexiste uma abordagem favorável à produção econômica e ao desenvolvimento.

Assim, o objetivo geral da investigação foi demonstrar a Sociologia como uma ciência da desigualdade e da má distribuição em detrimento da observância a fatores de produção de riqueza e promoção do desenvolvimento. Não obstante, procurávamos ali a menção à ideia-força do capital social, intimamente aproximativa da temática do desenvolvimento ${ }^{3}$. Na leitura dos sumários dos manuais é possível observar a quase ausência de termos como capital social, desenvolvimento e, evidentemente, desenvolvimento regional. Enquanto isso, os conteúdos revelam uma abordagem incontestavelmente pessimista em relação ao modo de produção

\footnotetext{
${ }^{3}$ Embora não seja novidade nas Ciências Sociais, é conveniente lembrar de sua definição como conjunto de fatores sociais, entre os quais a solidariedade, o associativismo, o cooperativismo, o diálogo, a confiança e o civismo. Autores contemporâneos como Robert D. Putnam (1996), James Coleman e Francis Fukuyama (1996), entre outros, oferecem contribuições importantes a respeito.
} 
capitalista e, por decorrência óbvia, ao liberalismo econômico. Dentro dos limites da mencionada investigação e de seu diagnóstico, nossa sugestão é categórica: a inserção do capital social e termos congêneres ao tema do desenvolvimento regional traria contribuições à Sociologia. Permitiria a novas gerações de leitores entenderem, em relação ao desenvolvimento, aquilo que a Sociologia dos manuais tem desprezado.

Nesse trabalho ainda não publicado, sugerimos que a abordagem dos manuais brasileiros de Sociologia que conhecemos é implicitamente antievolucionista, embora isso nada tenha a ver com o criacionismo. E, quando o antievolucionismo é explícito, revela um antidarwinismo reducionista, ignorando o seu desenrolar durante o Século XX, que Piotr Sztompka chama de "evolução da evolução"4. Por extensão, isso tem limitado as possibilidades de uma abordagem mais abrangente acerca do desenvolvimento, termo consanguíneo. Nos manuais de abordagem historiográfica sobre o surgimento da Sociologia, aprendemos que o darwinismo social serviu como teoria pseudocientífica a justificar a dizimação e a dominação colonial de europeus sobre os povos do "novo mundo". A ideia dos primeiros darwinistas sociais era simples e agressiva: a luta pela sobrevivência no mundo social seria equivalente à luta pela vida no mundo da natureza. A evolução dos seres humanos em sociedade seguiria a mesma lei da evolução das espécies na natureza em geral.

Seja na natureza ou em Sociedade, essa evolução teria duas características fundamentais, que apresentamos na forma de dois binômios, a saber: 1) adaptação/competição e 2) egoísmo/individualismo.

\section{Competição}

A primeira característica é a capacidade adaptativa das espécies às condições da natureza e à superação das adversidades. No caso do mundo animal e vegetal, em geral, o processo é essencialmente adaptativo, de mutação genética em função das circunstâncias e necessidades de superação. No caso dos seres humanos, essa adaptação não seria tão somente uma capacidade de automutação, em função das circunstâncias. Seria, principalmente, uma capacidade de mutação das circunstâncias em função das necessidades ou escolhas humanas. Mais que adaptação, pela inteligência superior e habilidades manuais e de linguagem, humanos são capazes de dominar a natureza e utilizá-la em seu benefício. Foi o que propiciou o desenvolvimento da técnica e da ciência. No caso humano, adaptar-se significaria dominar as circunstâncias e adversidades. A evolução seria determinada pela luta

\footnotetext{
${ }^{4}$ Cf. Piotr Sztompka (1998, p. 188). Note-se que este mesmo autor faz uma extensa revisão do evolucionismo na sociologia em três capítulos (SZTOMPKA, 1998, p. 177-246).
} 
sangrenta pela vida, em que os mais fortes sobreviviam às circunstâncias dominando a natureza, eliminando ou sobrepujando os mais fracos. Nessa perspectiva, os europeus estariam no topo da escala evolutiva.

Ora, isso explicava convenientemente o processo "civilizatório" de dominação dos europeus sobre outros povos. Entretanto, aqui a porca torce o rabo, pois é justamente nesse estágio de desenvolvimento do pensamento social que vemos emergir a característica mais fascinante e típica da análise sociológica, qual seja, a postura crítica ao pensamento convencional. É de responsabilidade da Sociologia a denúncia ao caráter eurocêntrico do darwinismo social. É a Sociologia que, com o auxílio de antropólogos e outros cientistas sociais, desmistificará o discurso evolucionista como um subterfúgio à dominação sangrenta ou ideológica dos europeus sobre os povos, ora dizimados, ora colonizados e subjugados pela força das armas, dos valores, das técnicas e do modo de produção. Sua tradição crítica é sua inevitável e grandiosa contribuição ao pensamento ocidental, qual seja, a denúncia contra a injustiça e a desigualdade. Em nome da evolução, os darwinistas sociais tentavam justificar tais fenômenos pela ciência. Em nome da ciência, a Sociologia tratou a evolução como falácia.

Essa crítica está implícita nos manuais de Sociologia tanto quanto é reproduzida em artigos preliminares, sugerindo que "o grande equívoco do darwinismo social foi atribuir valores sociais a uma tese científica que explicava um fenômeno biológico (...)". E que "O fato de a luta pela sobrevivência ocorrer na natureza selvagem não legitima absolutamente nada sobre a sua aplicação a um contexto social" (ROSSETTI, 2018). Esse modo de observação denunciativa sobre o pensamento social do Ocidente deu corpo e tradição à Sociologia. E, ainda que lógico-dedutiva, a sedução discursiva que a crítica sociológica exerce desde então nas mentes de jovens inquietos e idealistas é compreensível. Afinal, a crítica é o sal da vida e, como dizia um velho liberal, quem não é socialista aos 20 anos não tem coração ${ }^{5}$. Nessa perspectiva, a sempre bem formulada crítica sociológica abastece corações e mentes, convencendo-nos de que "o que o darwinismo social fez foi desviar as ideias de Darwin de seu curso original (...) para forçar a validação de um discurso ideológico de orientação liberal que tentava legitimar a ideia de que (...) seria eticamente válida (...) a eliminação dos 'mais fracos"' (Ibidem).

Nessa linha, uma importante crítica aparece no livro da socióloga Cristina Costa, intitulado "Sociologia: Introdução à Ciência da Sociedade". Sua última edição é de 2011, ano anterior à primeira lista de livros de Sociologia recomendados pelo MEC, em que somente dois livros foram recomendados, de um total de 14 obras $^{6}$. A não inclusão no PNLD não invalida a interpretação que Cristina Costa nos oferece, uma

\footnotetext{
${ }^{5}$ A frase é atribuída ao legislador e jornalista francês Georges Clemenceau (1841-1929).

${ }^{6}$ Os livros recomendados para o triênio 2012-2014 foram Bomeni e Medeiros (2013), cuja primeira edição é de 2010 , e também Tomazi (2013), cuja primeira edição é igualmente de 2010.
} 
vez que converge com a crítica ao capitalismo, explicitada nos manuais de Sociologia que encontramos nas bibliotecas das escolas e universidades brasileiras. A autora procura demonstrar como o pensamento de Darwin teria sido deturpado em favor de explicações proto-sociológicas que tentavam explicar a superioridade moral e tecnológica dos europeus sobre outros povos. Tratava-se da justificativa necessária ao processo de sujeição colonial. $\mathrm{Na}$ opinião da socióloga, a transferência da percepção de Darwin para o universo das relações sociais provocou "desvios interpretativos graves, que legitimaram ações movidas por preconceitos e interesses particulares" (COSTA, 2005, p. 33).

A interpretação de Cristina Costa não é improcedente. A autora acusa o darwinismo social de transpor equivocadamente o conceito de espécie para a análise do comportamento humano, ignorando a multiplicidade cultural e étnica existente entre as sociedades e no interior delas. A cultura, no final das contas, é o elemento que explica por que os seres humanos escaparam da seleção natural, ao serem capazes de transformar a natureza e dela se utilizar, ao invés de simplesmente a ela se adaptarem. Não há uma negação plena da ideia evolucionista. Concordando com outros autores, Costa relativiza o evolucionismo, sugerindo critérios mais "amplos, flexíveis e relativos, que deem conta da maravilhosa complexidade da cultura humana" (Ibidem). Mas não esquece de acusar o neoliberalismo como espaço ideológico onde o darwinismo social aparece para justificar a competição e a sobrevivência do mais apto, legitimando as leis do mercado. Ela sugere que o livre mercado é somente uma das formas de organização de relações sociais específicas, assim como outras formas, "mutáveis e relativas" (Ibidem, p. 34).

A crítica ao eurocentrismo é ainda mais justificável quando Cristina Costa denuncia a falta de reconhecimento da diversidade cultural. Nessa direção, o uso da perspectiva evolucionista para justificar a subjugação arbitrária e a imposição de valores e formas de administração da vida política, econômica e moral é igualmente compreensível e útil a uma visão crítica sobre o darwinismo social. Mas é só. Conquanto a autora perceba a presença contemporânea do evolucionismo na abordagem "neoliberal", dá o assunto por encerrado, como se não houvesse mais a dizer sobre algo irrelevante. Assim, o darwinismo é abandonado sem maiores explicações, fazendo o leitor presumir que nada além de um evolucionismo vulgar persiste por força de uma "orientação liberal" que não somente Costa, mas, em geral, os autores da Sociologia introdutória tratam com desprezo ou indiferença. Dão o caso por encerrado, como se não passasse de um sopro reacionário e mal redivivo no neoliberalismo, tal qual um zumbi. Não percebem, ou não querem perceber, que tudo em relação ao evolucionismo continua em aberto e pulsante, sobretudo pela "carga genética" transferida ao conceito de desenvolvimento. 


\section{Egoísmo}

$\mathrm{Na}$ Sociologia brasileira, em geral, a identificação com a "orientação liberal” reforça a aversão ao darwinismo social, levando-nos a segunda característica da abordagem evolutiva: o individualismo egoísta. As especulações de Herbert Spencer (18201903) sobre o evolucionismo para justificar sua concepção liberal evolucionista foram igualmente combatidas. Entre outras ideias, Spencer promovia a comparação entre o organismo animal e "o organismo social". Na sua tentativa organicista de entender o funcionamento da sociedade e dos indivíduos, sugeria que as elas funcionariam como corpos vivos. A diferença entre a fisiologia animal e a social estaria no fato de que entre os primeiros haveria uma espécie de consciência relacionada à preservação do todo, enquanto na segunda essa consciência estaria em cada indivíduo. Assim, não seriam os indivíduos que existiriam funcionalmente para a preservação do organismo social, mas ao contrário, a sociedade é que teria a função geral de preservação dos interesses individuais. Isso caracterizaria a proeminência do individual sobre o coletivo (ACTON, 2018).

Tal pressuposto está longe de ser exclusivo ao pensamento de Spencer, já que a encontramos na raiz dos contratualistas e, a rigor, do Renascimento e do Iluminismo, dos quais somos herdeiros. Essa proeminência do individualismo é a característica central do liberalismo, convenientemente associada ao evolucionismo e seu caráter essencialmente egoísta. Nessa perspectiva, o desconforto e a oposição que causa é inevitável, ante a abordagem sociológica hegemônica no Brasil, onde nem o evolucionismo nem o liberalismo se encaixam. Comprometida não apenas com o entendimento do mundo, mas com a sua transformação, a Sociologia não pode ceder aos encantos e desencantos do real e hodierno. Seu fundo moral pressupõe o homem bom por natureza, cuja Sociedade, que predomina sobre os indivíduos, perverteu tal característica e cabe restituí-la. Por isso, a ética sociológica requer o engajamento humanitário radical por meio da crítica revolucionária, altruísta, e coletivista, quando não romântica, sobretudo utópica, comprometida com o amor e o bem-estar?

Essa perspectiva altruísta parece, de fato, incompatível com o pressuposto evolucionista da luta pela sobrevivência. Se a preservação da vida está em primeiro plano e exige a luta constante, então o amor e o bem-estar geral permanente não passariam mesmo de uma utopia. O cenário hobbesiano do "homem lobo do homem" não menos seria que a expressão essencial do que acontece na natureza da qual, evidentemente, fazemos parte. Por essa razão, a felicidade não passaria de uma

\footnotetext{
${ }^{7}$ Essa posição é uma característica da Sociologia de orientação marxista, associada a prerrogativas da doutrina social da Igreja Católica, estabelecidas a partir do início dos anos 1960, após o Concílio Vaticano II. Subsequentemente, aconteceriam a Reunião dos Bispos da América Latina, em Medelín (1968) e a Reunião de Puebla (1979), nas quais, respectivamente, a Igreja Latino-Americana faz e reafirma a opção preferencial pelos pobres.
} 
doce ilusão, um autoengano coletivo, útil, porém, falacioso. Por extensão disso, caberia aceitar a desigualdade desde sempre existente como um desígnio da natureza. Assim, só nos restaria o conformismo apolínio ou a disposição dionisíaca de participarmos dessa disputa eterna, já que não adiantaria fugir à fatalidade biologicamente estabelecida. Essa era a tese proferida pelos evolucionistas e racialistas do Século XIX (TOMAZI, 2013, p. 245).

Diante disso, o esforço do raciocínio sociológico produzido por alguns antropólogos ofereceu a importante narrativa da cultura (Ibidem), aparentemente impulsionada pela crença epicurista na capacidade humana do desvio. Aliás, o conceito de cultura, como sabemos, é fundamental à Sociologia justamente por permitir aos aprendizes dessa "ciência" entenderem-na como o artifício humano que nos distingue dos outros seres vivos. Nesse sentido, salvaguardando as descobertas empiricamente comprovadas por Darwin para o mundo da natureza, parte importante dos pensadores sociais passaram a afirmar que os humanos escapariam dos determinismos naturais justamente pela capacidade de produzirem cultura. Essa afirmativa, podemos encontrá-la na importante crítica do anarquista russo Piotr Kropotkin (2009) aos darwinistas sociais. Em fins do Século XIX, esse autor combatia o pressuposto da competição entre os humanos com sua tese do "apoio mútuo" como fator essencial no esforço pela sobrevivência. E a mesma ideia da cooperação entre os seres vivos pode ser encontrada no trabalho dos biólogos Humberto Maturana e Francisco Varella (1995).

Esse debate inacabado contrapondo a competição e a cooperação entre os seres vivos, sobretudo entre os humanos, é, no mínimo, instigante. E, ainda que não permita uma conclusão categórica e definitiva, ambas as teses seriam úteis e, no entanto, estão ausentes do debate sociológico contemporâneo. As abordagens que advogam pela competição poderiam despertar importantes reflexões em dois sentidos, a saber: primeiramente, permitiriam o entendimento acerca da importância que o esforço individual representa na vida de cada indivíduo, não obstante, os efeitos nos grupos e nas sociedades. Por extensão, as mesmas abordagens sobre a competição abririam um leque de indagações e especulações, inclusive ao conhecimento já existente, sobre as capacidades e potencialidades produtivas e competitivas de países, regiões e cidades. Mas sabemos da antipatia e das críticas, por vezes procedentes, ao conceito de competitividade no meio escolar e nas ciências humanas ${ }^{8}$.

Não obstante, as abordagens acerca dos processos de cooperação nas mais variadas esferas das relações sociais são igualmente desprezadas. A ajuda mútua acontece desde as relações de vizinhança, passando pelas organizações produtivas, pelo funcionamento dos sistemas econômicos, até a esfera da política, das relações entre

\footnotetext{
${ }^{8}$ Nessa direção, a tese de doutorado de Saneh (2010) é elucidativa e apresenta muito bem a crítica à ideia-força da competição. Ali, a competitividade é apresentada como um conceito inserido no universo educativo com o objetivo de estimular a lógica do mercado em oposição à ideia de solidariedade e inclusão social.
} 
indivíduos e das sinergias entre o Estado e a sociedade. Novamente, convém lembrar que a literatura acerca do capital social é farta desde os anos 1990 do século XX. E estudos sobre fenômenos congêneres como a confiança, o diálogo e a cooperação, além do civismo, da solidariedade e do associativismo enriqueceram as reflexões sobre o desenvolvimento regional. Foram produzidos por cientistas políticos, economistas, antropólogos e geógrafos, mas também sociólogos. Além disso, as conexões interdisciplinares com áreas do conhecimento como a Biologia e a Física também possibilitam sinapses desprezadas na Sociologia introdutória. Por extensão, tais estudos têm contribuído para a própria percepção sobre as formas de evolução social que os indivíduos desenvolvem ao longo da vida em sociedade e na luta pela vida.

\section{Competição e cooperação são complementares}

O que nos parece mais importante aqui é que, por mais contrapostas que sejam, as teses da competição e da cooperação não são excludentes entre si. Independentemente da oposição entre elas, o fato é que no mundo real os fenômenos da cooperação e da competição convivem entre si, como atestaria a teoria dos contrários. A abordagem em favor da cooperação entre atores políticos, econômicos e culturais entre si não exclui o fato de que cooperam, entre tudo, para se protegerem de outros conjuntos de atores e de competirem com esses grupos. É dessa forma que a própria ideia de evolução pode ser sintetizada. Nesse aspecto, um dos melhores trabalhos sociológicos é o do cientista político nipo-americano Francis Fukuyama (1996). Em seu livro intitulado "Sociedade da Confiança", ele demonstra como as três economias mais competitivas do Século XX (EUA, Japão e Alemanha) o são justamente pela capacidade cooperativa de agentes econômicos e políticos.

Esse tipo de abordagem é convergente com a ideia da solidariedade orgânica de Durkheim para a análise da divisão do trabalho social nas sociedades industriais. A propósito, o conceito é subsequente ao de solidariedade mecânica justamente para distinguir as sociedades primitivas das contemporâneas. Nesse sentido, trata-se de um conceito essencialmente evolucionista, tanto quanto o pensamento de seu autor. Obrigatório na introdução à Sociologia, o conceito de solidariedade poderia ser atualizado. Isso permitiria demonstrar como a capacidade de cooperar, de construir redes de relações de interdependência e de mantê-las pode diferenciar as sociedades e permitir a sua evolução. Pode, inclusive, ajudar a explicar por que algumas superam certos obstáculos, enquanto outras não. Nessa direção, também é útil lembrar o trabalho do físico chileno do Massachussets Instituto f Technology MIT, Cesar Hidalgo. Interessado em compreender a complexidade do funcionamento das economias competitivas, o autor afirma que a principal característica é justamente a capacidade de reunir agentes de diferentes 
conhecimentos capazes de cooperar entre si, realizando tarefas complexas (HIDALGO, 2015; 2017). A aproximação com o conceito de divisão do trabalho social de Durkheim não poderia ser mais oportuna.

Essa possibilidade de reflexão interdisciplinar sobre um mesmo tema de significativa compreensão sociológica tem sido dispensada pelo núcleo duro da iniciação sociológica - leia-se os autores dos livros didáticos. E o principal produto gerado nessa terra fértil da interdisciplinaridade é justamente a fusão entre a cooperação e a competição. Vale lembrar que autores opostos entre si e aqui citados admitem a convivência dos dois fenômenos nos comportamentos dos animais, incluindo os seres humanos, sem problemas. Darwin, Kropotkin, Maturana e Varela são só alguns desses autores. Nessa perspectiva, é conveniente a recorrência ao zoólogo Richard Dawkins, que sugere que o erro de muitos darwinistas estaria em considerar toda a análise a partir da premissa dos indivíduos e não dos genes. Afirmando sua tese sobre a característica egoísta dos genes, o autor observa, entretanto, que o comportamento deles é cooperativo por uma simples percepção sobre as vantagens da cooperação para a autopreservação.

Seja como for, pouco deveria preocupar à Sociologia e às Ciências Humanas em geral, se o ser humano é altruísta ou egoísta, competitivo ou cooperativo, já que as duas "naturezas" convivem entre si. Talvez devêssemos, ainda, substituir o termo "natureza humana" por "condição humana", no sentido de livrarmo-nos de um conceito espinhoso. Só não o fazemos porque a ideia de "natureza" foi instrumental no desenvolvimento do pensamento social, até representar o antônimo à ideia de cultura, tão apropriada pelas Ciências Humanas em oposição à ideia de natureza. Esta última sempre nos pareceu uma variável analítica que as humanidades em geral cultivam como meta teleológica na construção de um ser humano genuinamente bom e livre. Independentemente disso, de forma subjacente ou explícita, a Sociologia trabalha com essa dualidade o tempo todo. Entretanto, trata o egoísmo e a competição como uma realidade a ser superada, e o altruísmo e a solidariedade como um fim a ser alcançado.

De toda maneira, é possível partir de um pressuposto altruísta ou simplesmente da ajuda mútua, embora não sejam a mesma coisa. A Sociologia introdutória que se desenvolveu no Brasil é vinculada à matriz latino-americana, que advém da opção preferencial pelos pobres. Esta concepção foi desenvolvida pelo catolicismo no contexto do Concílio Vaticano II, advindo daí o pressuposto altruísta nas entrelinhas dos manuais de Sociologia. Em geral, insinua uma condição humana genuinamente boa, livre e de igualdade entre os homens, a partir da qual pensa deva organizar-se a Sociedade, não obstante reconheça nela um conflito a ser superado, uma desigualdade a ser combatida e uma justiça a ser restabelecida. É difícil abrir mão dessa "premissa original", uma vez que não devemos ignorar o público leitor dos manuais, basicamente composto de jovens em formação moral e uma concepção antropológica do "bom selvagem" parece mais convidativa. Mas se a 
Sociologia estiver escamoteando o lado "lobo do homem", então torna vulnerável e negligente sua condição de ciência, ao não advertir seus leitores.

Já as abordagens sobre o capital social, por exemplo, diferem desse posicionamento por dispensarem o fundo moral que impulsiona a Sociologia, mas que interfere na sua objetividade analítica. Em geral, os autores do capital social percebem as vantagens da cooperação, mas raramente se perguntam se ela tem um fundo altruísta ou não. Simplesmente é possível tratar os seres humanos como agentes racionais que cooperam porque percebem as vantagens disso, e nada mais é necessário dizer. Inintencionalmente, a própria Sociologia introdutória o faz, como já dissemos, quando apresenta o conceito de solidariedade orgânica de Emile Durkheim. Ali, está pressuposto que os indivíduos cooperam conscientemente na divisão do trabalho social. Poderia, inclusive, tomar esse conceito clássico durkheimniano como o eixo de inserção de uma abordagem completa sobre o tema do capital social e seus fenômenos constitutivos, abrindo um novo capítulo nos manuais de Sociologia. Mas isso é totalmente desprezado.

A maioria dos livros e artigos sobre o capital social está relacionada ao tema do desenvolvimento. Por extensão, não há nada que impeça a relação conceitual do capital social com o evolucionismo. As abordagens dos autores enfatizam a importância deste fenômeno e seus congêneres - a cooperação, o associativismo, a solidariedade, a confiança mútua, o diálogo e o civismo. Normalmente, estão preocupados em apontar as causas do desenvolvimento econômico, mas também político de nações, regiões e cidades. Com o perdão da redundância, frequentemente a preocupação dos autores está em querer saber e sugerir as razões da prosperidade. E, como já exemplificamos ao mencionar o trabalho de Francis Fukuyama, com muita frequência esses autores, principalmente os economistas, relacionam os fatores vinculados ao capital social como a causa fundante da capacidade competitiva. $\mathrm{Na}$ leitura desses autores, o que explica a competitividade de uma nação ou região é a cooperação. Portanto, a oposição entre os termos desaparece, o desenvolvimento se explica e o evolucionismo segue.

Nesse sentido, queremos insistir: nossa crítica à Sociologia dos manuais está em afirmar que sua apresentação como ciência e a análise de seus objetos contém um fundo moral altruísta. Entretanto, o erro implícito ao raciocínio sociológico não está em insinuar a defesa do altruísmo. Não há mal nisso, ainda que seja talvez uma ficção, como sugerem autores como Dawkins. O erro da Sociologia está em negar, isto é, em combater o egoísmo. Não exatamente em negar a sua existência, já que as desigualdades sociais o atestam e elas são denunciadas o tempo todo. Nesse sentido, o objeto mais obsessivo da Sociologia é justamente o tema da desigualdade social, que contém o gérmen do egoísmo. O problema dessa Sociologia é que ela se nega a admitir que uma sociedade de indivíduos mais ou menos egoístas seja capaz de resolver seus problemas, de evoluir e desenvolver-se. De modo quase hobbesiano, nega-se, implicitamente, a possibilidade de que homens livres e ambiciosos sejam capazes de cooperar entre si sem eliminar o fato de que ajam por 
motivações egoístas. Nas entrelinhas, é a rejeição da mão invisível pela do Estado que permeia toda a argumentação. É nesse sentido que dizemos que é hobbesiano.

Mesmo que o leitor aqui não concorde e receba como uma arbitrariedade, a analogia organicista para a compreensão dos fenômenos sociais nos parece tão aceitável quanto às advertências a sua utilização na Sociologia. O conhecido argumento é o de que humanos escapam do determinismo da natureza desde que criam a cultura. Não obstante, como sugerem os adeptos da Sociobiologia, humanos continuam sendo organismos pertencentes ao mundo da natureza. É nessa perspectiva, sempre discutível, que entendemos, por exemplo, a leitura de um zoólogo e também evolucionista como o incompreendido Richard Dawkins. O autor é contestado pelo significado que sua tese sobre o gene egoísta adquiriu no mundo científico, embora nem sempre seu livro tenha sido lido ou devidamente interpretado a respeito?. Assim, ao largo da rejeição ao organicismo na Sociologia, a análise dos organismos como colônias de genes nos parece passível de comparação com as sociedades humanas.

O título do livro de Dawkins é um tanto omissivo, por esconder uma análise parcialmente paradoxal ao que sugere. Ao descrever as estratégias de sobrevivência dos genes, de geração a geração, o autor afirma que a cooperação seria resultado do próprio egoísmo. Apesar da natureza egoísta dos genes, eles "colaboram e interagem de maneiras inextricavelmente complexas, tanto uns com os outros como com seu ambiente externo" (DAWKINS, 1979, p. 25). Na sequência, o zoólogo observa que "não há nenhum gene que, por si só, construa uma perna, longa ou curta. A construção de uma perna é um empreendimento de cooperação entre muitos genes" (Ibidem, p. 25). Já que a construção dos organismos depende de muitos genes, a seleção natural priorizaria os mais hábeis na tarefa primordial de cooperar. Isto "porque o 'ambiente' de um gene consiste de outros genes, cada um dos quais, por sua vez, sendo selecionado segundo sua habilidade de cooperar..." (Ibidem, p. 27). $\mathrm{Na}$ perspectiva da competição pela sobrevivência, "A seleção favoreceu os genes que cooperam entre si" (Ibidem, p. 31). E, prossegue, observando que "Na competição ferrenha por recursos escassos, na luta implacável por comer outras máquinas de sobrevivência e evitar ser comido, deve ter havido um prêmio para a coordenação central e não para a anarquia dentro do corpo comum" (Ibidem, p. $31)$.

$\mathrm{Na}$ verdade, o zoólogo Richard Dawkins está confrontando seus críticos, que afirmam que a base da explicação evolucionista está na unidade egoísta dos corpos em luta pela sobrevivência. Dawkins pressupõe que não sejam os corpos estruturados e egoístas que adquirem consciência e a partir dela passam a lutar pela sobrevivência. Embora pareça exótico, ele sugere que são os genes egoístas que, em

\footnotetext{
${ }_{9}$ Um exemplo, entre muitos, está na dura crítica realizada por Jag Bhalla (2013), numa resenha em que procura desqualificar a tese do "gene egoísta". Por outro lado, a resenha de J. R. Leite (2015), ao contrário, elogia a obra e afirma que ela poderia ser compreendida como um "antídoto ao egoísmo".
} 
busca da perpetuação, exercem o comando sobre os corpos por eles estruturados. Não obstante, a partir desse ponto de divergência com seus críticos, ele sugere que esses genes egoístas que sobreviveram ao longo da evolução conseguiram esse feito justamente por desenvolverem estratégias de cooperação. Nessa perspectiva, o trabalho cooperativo dos genes seria tão eficiente que teria gerado a própria ilusão do organismo egoísta. Nessa direção, assevera que "hoje em dia a intrincada evolução conjunta mútua dos genes estendeu-se a tal ponto que a natureza coletiva de uma máquina de sobrevivência individual é praticamente irreconhecível. Muitos biólogos, de fato, não a aceitam e discordarão de mim. ” (Ibidem, p. 31)

Em toda a extensão de "O Gene Egoísta" Richard Dawkins está a tratar a compreensão do processo evolutivo como baseado em estratégias cooperativas dos genes no interior dos organismos animais e vegetais. Para ele, essas estratégias caminham "no sentido de 'instruir' suas máquinas de sobrevivência não quanto a aspectos específicos, mas quanto a estratégias e truques gerais da arte de viver" (Ibidem, p. 31). Ainda que Dawkins estivesse no terreno da lógica dedutiva, não parece haver razão para que a Sociologia ignore tais especulações oriundas das ciências naturais. Ao contrário, se conferimos importância à dimensão interdisciplinar, podemos ampliar o horizonte reflexivo e produzir novas sinapses. O conceito de evolução seria mais bem compreendido na medida em que a perspectiva interdisciplinar elimina o antagonismo entre competição e cooperação, como estamos sugerindo. Isso ajudaria a Sociologia a aumentar seu espectro interpretativo sobre uma realidade social que os sociólogos e mesmo outros cientistas não deveriam tratar como um campo exclusivo das humanidades.

Nessa exata direção tampouco deveríamos recriminar interpretações sociológicas por analogia metodológica à Biologia, especificamente à Zoologia. É a perspectiva do sociólogo italiano Joseph Lopreato (1928-2015), da Universidade de Yale. Pretendemos analisar a obra deste autor em artigo próximo, bastando, por hora, lembrar da convergência de sua proposição geral com o que expomos aqui. Sua inquietação com os rumos da Sociologia proliferou na incursão à Biologia, como revela o título de seu último livro. No prefácio de "Crisis in Sociology: a need for Darwin", Lopreato insiste na urgência de uma Sociologia interdisciplinar e defende a aproximação com a Biologia evolucionista. Segundo ele, esta ciência evolui justamente por sua disposição interdisciplinar, em aproximação com a neurociência e a psicologia darwiniana. Lopreato estava convicto de que tal aproximação seria imperiosa à própria sobrevivência da Sociologia. E quaisquer que fossem os resultados, lembrava que as analogias são "meios de trabalho normais na ciência" (LOPREATO, 1999).

Por analogias, isto é, pelo uso de explicações por comparação e semelhança na Sociologia, entenda-se a recorrência da análise sociológica ao recurso da metáfora com alguma ciência. É isso que ocorre quando, para explicar a realidade social, a Sociologia pode se utilizar da engenharia, da computação. Muito mais comum é o auxílio à Biologia ou à Física, como fez seu fundador, Augusto Comte, e como 
fizeram os adeptos do execrado organicismo nas Ciências Sociais. Em outras palavras, recorramos também a uma metáfora ao sugerir que esse recurso analógico funciona como se usássemos uma dessas ciências como plataforma analítica. No interior desta, teríamos um conjunto de referências analógicas à disposição, funcionando como um recurso econômico a facilitar a explicação. É desse modo que Dawkins sugere o retorno da teoria da evolução às Ciências Humanas, embora tal sugestão ainda seja vista com desdém e preconceito por conta das simplificações grosseiras dos velhos darwinistas sociais.

Contudo, o encerramento da discussão em torno da validade do evolucionismo social na Sociologia é igualmente equivocado, além de arbitrário. Tanto quanto, o reducionismo interpretativo dessa corrente de pensamento ao darwinismo social é outra simplificação grosseira. Mais do que isso, sendo a inexistência do evolucionismo uma decisão consensual na abordagem da Sociologia introdutória, trata-se de um posicionamento anticientífico. Assim o é por uma simples razão, já mencionada, qual seja, a existência de uma ampla revisão do evolucionismo social, realizada desde a segunda metade do Século XX. Longe de finalizada, essa revisão continua em curso e é provável que seja tão continua quanto o curso da história. Embora não haja consenso sobre isso, a maior comprovação de sua atualidade, podemos afirmar, é o necessário esforço de reflexão sociológica sobre os desafios contemporâneos do desenvolvimento. Isso inclui o tema do desenvolvimento regional e todas as ideias-força e conceitos utilizados num esforço investigativo cada vez mais interdisciplinar. O que, então, a Sociologia introdutória está esperando?

\section{Conclusão}

As relações analíticas e interpretativas que a Sociologia poderia estabelecer vão desde a Biologia, passando pela Economia, pela Filosofia liberal, até chegar à Física e às chamadas Ciências da Computação. E não deveria haver receio em fazê-lo, a começar pela Economia, uma Ciência Social. Bastaria a disposição em aceitar a perspectiva de uma economia livre, baseada, sobretudo, nas iniciativas advindas da própria Sociedade dos indivíduos, sem o pressuposto exclusivista do racionalismo estatal. Não se trata de, inversamente, excluir a ação dos governos, mas de perceber que o desenvolvimento não é sua exclusividade. Antes mesmo, os fatores que o favorecem podem estar nas formas de organização social espontâneas, na cultura e nas instituições formais e informais, sem que os governos estejam necessariamente por trás de cada êxito da Sociedade. É assim que autores têm explicado o desenvolvimento econômico, compreendendo-o como oriundo de fatores sociologicamente interpretáveis, algo que tem passado despercebido à Sociologia introdutória. E, por vezes, as contribuições vêm de autores de áreas distantes.

É nessa perspectiva não apenas interdisciplinar, mas intercientífica, que sugerimos deva a Sociologia abrir seu campo analítico e interpretativo. Embora seja desejável 
e fosse útil ao debate, ainda não nos é possível apresentar sentenças em favor dessa sugestão. O caminho investigativo, no entanto, está aberto e estamos seguros de que as tentativas devem ser feitas. É possível que os resultados demonstrem limitações indesejáveis e sejamos constrangidos a retroagir e mesmo admitir que não há muito a ser feito. De todo modo, as analogias entre o mundo da natureza e a Sociedade têm resistido às críticas, colocando estas em periódica suspeição. E são as próprias circunstâncias da vida social que, sociologicamente definidas pela ideia de "processo" (SZTOMPKA, 1998), trazem à tona as contendas mal definidas da ciência. Nessa direção, os efeitos sociais causados pelo processo de globalização ou mundialização trouxeram de volta preocupações adormecidas. Exemplo disso é o desenvolvimento, agora com o apêndice adjetivo de regional. Com ele, nos parece ressurgir o tema do evolucionismo e ganha força o método interdisciplinar e porque não o dizer? - intercientífico.

\section{Referências}

ACTON, Harry Burrows. Herbert Spencer. In: Encyclopaedia Britannica, dez/2018. Disponível em http://www.britannica.com/biography/HerbertSpencer. Acesso em: 23 fev. 2020.

ARAUJO, S. M. de; BRIDI, M. A.; MOTIM, B. L. Sociologia (vol. único; ensino médio). São Paulo: Scipione, 2013.

BHALLA, Jag. Selfish genes also most cooperate. In: Scientife American [Guest Blog]. Jun, 2013. Disponível em: http:/ / blogs.scientificamerican.com/guestblog/selfish-genes-also-must-cooperate. Acesso em: 23 fev. 2020.

BOMENI, Helena; MEDEIROS, Bianca Freire et al. Tempos modernos, tempos de sociologia. São Paulo: Editora do Brasil, 2013.

BRASIL. Base Nacional Curricular Comum. $2^{a}$ revisão. Brasília: Ministério da Educação, 2016.

BRASIL. Guia de livros didáticos PNLD 2015. Brasília: Ministério da Educação, 2014. 
BRASIL. Guia de livros didáticos: PNLD 2015: Sociologia: ensino médio. Brasília: Ministério da Educação/Secretaria de Educação Básica, 2014a. Disponível em: http://www.fnde.gov.br/pnld-2018. Acesso em: 15 set. 2016.

BRASIL. Guia de livros didáticos: PNLD 2015: Sociologia: ensino médio. Brasília : Ministério da Educação/Secretaria de Educação Básica, 2014b. Disponível em: file://C:/Users/cliente/Downloads/pnld_2015_sociologia.pdf. Acesso em 15 set. 2016.

BRASIL. Guia de livros didáticos: PNLD 2012: Sociologia. Brasília: Ministério da Educação/Secretaria de Educação Básica, 2011. Disponível em:file://C:/Users/cliente/Downloads/GuiaPNLD2012_SOCIOLOGIA.pdf. Acesso em: 15 set. 2016.

COSTA, C. Sociologia: introdução à ciência da sociedade. São Paulo: Moderna, 2005.

DAWKINS, Richard. O Gene Egoísta; Tradução Geraldo H. M. Florsheim. Belo Horizonte: Editora Itatiaia, 1979. Disponível em:

http://www2.unifap.br/alexandresantiago/files/2014/05/Richard_Dawkins_O_ Gene_Egoista.pdf. Acesso em: 15 nov. 2018.

FUKUYAMA, F. Confiança: as virtudes sociais e a criação da prosperidade. Rio de Janeiro: Rocco, 1996.

Fundo nacional de desenvolvimento da educação. FNDE 2015. Disponível em: https://www.fnde.gov.br/programas/programas-do-livro/pnld/guia-do-livrodidatico/item/5940-guia-pnld-2015. Acesso em: 15 jul. 2017.

BRASIL. Guia de livros didáticos: PNLD 2015: Sociologia: ensino médio. Brasília: Ministério da Educação/Secretaria de Educação Básica, 2014a. Disponível em: http://www.fnde.gov.br/pnld-2018. Acesso em 15 set. 2016.

BRASIL. Guia de livros didáticos: PNLD 2015: Sociologia: ensino médio. Brasília: Ministério da Educação/Secretaria de Educação Básica, 2014b. Disponível em: file://C:/Users/cliente/Downloads/pnld_2015_sociologia.pdf. Acesso em 15 set. 2016. 
BRASIL. Guia de livros didáticos: PNLD 2012: Sociologia. Brasília: Ministério da Educação/Secretaria de Educação Básica, 2011. Disponível em: http:// Downloads/GuiaPNLD2012_SOCIOLOGIA.pdf. Acesso em 15 set. 2016.

HIDALGO, Cesar. Why information grows: the evolution of orders, from atoms to economies. Basic Books, 2015. Disponível em: http:/ /www.creativante.com/new/index.php/2013-02-03-19-36-05/2015/259why-information-grows-porque-informacao-cresce. Acesso em: 15 dez. 2018.

HIDALGO, Cesar. Entrevista à Folha de São Paulo, em 25/09/2017, por Marcelo Soares. Disponível em: https://www1.folha.uol.com.br/ciencia/2017/09/1921443-acumulo-deconhecimento-por-um-pais-intensifica-a-economia-diz-fisico-o-mit.shtml. Acesso em: 24 mar. 2019.

KROPOTKIN, P. Ajuda Mútua: um fator de evolução. São Sebastião: A Senhora Editora, 2009.

LIMA, Aline Cristina da Silva; AZEVEDO, Crislane Barbosa de. A interdisciplinaridade no Brasil e o ensino de história: um diálogo possível. Revista Educação e Linguagens, v. 2, n. 3, jul.-dez. 2013. Disponível em: http://www.fecilcam.br/revista/index.php/educacaoelinguagens/article/viewFile /644/380. Acesso em: 17 fev. 2019.

LOPES, José Reinaldo. O gene egoísta de Richard Dawkins. In: Folha de São Paulo, Caderno Especial: Fronteiras do Pensamento, em 16/05/2015. Disponível em: https://www.fronteiras.com/artigos/gene-egoista-tambem-e-cooperacao. Acesso em: 09 jan. 2019.

LOPREATO, J.; CRIPPEN, T. Crisis in sociology: the need for Darwin. New York: Transaction Publishers, 1999.

MACHADO, I. J. de R.; AMORIM, H.; BARROS, C. R. de. Sociologia hoje. São Paulo: Ática, 2013. 
MATURANA, H.; VARELA, F. A árvore do conhecimento. Campinas: Ed. Psy, 1995.

OLIVEIRA, Luiz Fernandes; COSTA, Ricardo Cezar Rocha da. Sociologia para jovens do século XXI. São Paulo: Imperial Novo Milênio, 2013.

PUTNAM, Robert D. Comunidade e democracia: a experiência da Itália moderna. São Paulo: FGV, 1996.

ROSSETTI, Victor. Darwinismo social - o uso indevido das ideias de Darwin. NetNature Wordpress (sítio eletrônico), 2018. Disponível em: https:// netnature.wordpress.com/2018/08/14/darwinismo-social-o-usoindevido-das-ideias-de-darwin. Acesso em: 18 ago. 2018.

SANEH, Giuliano. Competição, irreflexão, conformismo: crítica à cultura da adaptação. 2010. Tese (Programa de Pós-Graduação em Sociologia Política) Centro de Filosofia e Ciências Humanas, UFSC, Florianópolis, 2010. Disponível em:

https:// repositorio.ufsc.br/bitstream/handle/123456789/93934/289383.pdf?seq uence $=1$. Acesso em: 17 jan. 2019.

SILVA, Afrânio et al. Sociologia em movimento. São Paulo: Moderna, 2013.

SOARES, Alisson Magalhães. Sociologia e sociobiologia: autonomia vs. (socio) biologização da sociologia. 2009. Dissertação (Programa de Pós-Graduação em Sociologia) - UFMG, Belo Horizonte, 2009. Disponível em: https:/ / repositorio.ufmg.br/bitstream/1843/BUOS8YNMLF/1/disserta_o._alisson_soares_2009._sociologia_e_sociobiologia.pdf. Acesso em 29 dez. 2018.

SZTOMPKA, P. A sociologia da mudança social. Trad. Pedro Jorgensen Jr. Rio de Janeiro: Civilização Brasileira, 1998.

TOMAZI, N. D. Sociologia para o ensino médio (vol. único). 3 ed. São Paulo: Saraiva, 2013. 
Walter Marcos Knaesel Birkner e Sandro Luiz Bazzanella

Endereço para correspondência:

Walter Marcos Knaesel Birkner-988188898wa@gmail.com

Rua 30 de agosto, 100 - Bairro Itoupava Norte

89065-210 Blumenau/SC, Brasil

Sandro Luiz,Bazzanella - sandroluizbazzanella@gmail.com BR 470, km 89, n. 630

89138-000 Ascurra/SC, Brasil

26 | Revista Brasileira de Desenvolvimento Regional, Blumenau, 7 (3), P. 5-26, 2019 